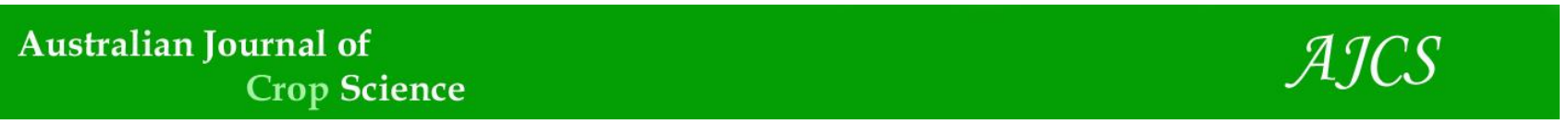

AJCS 11(09):1137-1145 (2017)

ISSN:1835-2707

doi: 10.21475/ajcs.17.11.09.pne624

\title{
In vitro cultivation of purple basil Ocimum basilicum L. 'red rubin' at different levels of salts, charcoal, sucrose and potassium iodine
}

\author{
Flávio Julian da Silva1 ${ }^{1}$, Andressa Bezerra Nascimento², Letícia Neris Barbosa² ${ }^{2}$ Hélida Mara \\ Magalhães*1
}

1Programs in Biotechnology Applied to Agriculture. Paranaense University, Mascarenhas de Moraes Square, 4282, 87502-210 Umuarama, Paraná, Brazil

2Paranaense University, Umuarama, Mascarenhas de Moraes Square, 4282, 87502-210 Umuarama, Paraná, Brazil

\section{*Corresponding author: helidamara@prof.unipar.br}

\begin{abstract}
Ocimum basilicum'red rubin' is highly valued for its essential oil, and is widely used in folk medicine, but few studies examining in vitro propagation techniques for this basil variety are available. We examined the development of red rubin basil seedlings grown in vitro in different concentrations of mineral salts, charcoal combined with sucrose, and potassium iodine in three series of tests. In the first series, five concentrations (0, 25, 50, 75 and 100\%) of Murashige and Skoog salts (MS culture medium) were used to germinate sterilized seeds of $O$. basilicum. In the second test, to evaluate the combined effects of charcoal and sucrose on basil growth, three concentrations of charcoal $(0,3.0$, and $4.5 \mathrm{~g} / \mathrm{L})$ and two of sucrose $(30$ and $60 \mathrm{~g} / \mathrm{L})$ were used. In the third test, the seeds were sown onto culture medium enriched with five different concentrations of potassium iodine $(0,25,50,75$ and $100 \mu \mathrm{M}) ; 0.5 \mu \mathrm{M}$ benzyl aminopurine (BAP) and $1.0 \mu \mathrm{M}$ naphthalene acetic acid (NAA) were added to all germination media. A completely randomized experimental design was used in all tests, with five replicates, four vials per test, and 4 seeds per vial. In Test 2, seedling oxidation $(\%)$ and the numbers of leaves and shoots were submitted to non-parametric analysis using the Kruskal Wallis test ( $\mathrm{p} \leq 0.05)$. The other data were submitted to analysis of variance $(p \leq 0.05)$. The qualitative means were evaluated by the Tukey test ( $\leq \leq 0.05)$, and the quantitative means by polynomial regression $(\mathrm{p} \leq 0.05)$. The results showed that $100 \%$ MS culture medium was most indicated for 'red rubin' seed germination and aerial portion production, while $70-80 \%$ MS was indicated for root production. A sucrose level of $30 \mathrm{~g} / \mathrm{L}$ (standard) combined with $4.5 \mathrm{~g} / \mathrm{L}$ of activated charcoal allowed the best seedlings development and inhibited callus formation. Activated charcoal limited copper and zinc uptake by $O$. basilicum seedlings, but not enough to hamper their development. Increasing concentrations of potassium iodine reduced all of the growth variables analyzed in this basil variety.
\end{abstract}

Keywords: Ocimum basilicum L., micropropagation, medicinal plant, culture medium.

Abbreviation: $\mathrm{AC}_{-}$activated charcoal, $\mathrm{APL}_{-}$aerial portion length, $\mathrm{BAP}_{-}$benzylaminopurine, $\mathrm{Cu}_{-} \mathrm{Copper}_{\text {; }} \mathrm{CSD} 1$ and CSD2_ gene families in Arabidopsis, DMAP_dry mass of the aerial portion, DMRC_ dry mass of the root or of the root + callus portion, FMAP_ fresh masses of the aerial portions, FMRC_ fresh masses of the root, KI_ potassium iodide, miRNAs_micro RNAs, MS_ Murashige and Skoog, NAA_ naphthalene acetic acid, NC- presence of callus, $\mathrm{NL}_{-}$number of leaves, $\mathrm{NS}_{-}$numbers of shoots, $\mathrm{OX}_{-}$oxidized plants, PVP_polyvinyl pyrrolidone, RL_root, SISVAR_statistical analysis system, SOD_superoxide dismutase, Zn_Zinc.

\section{Introduction}

Ocimum basilicum L. (family Lamiaceae), popularly known as basil, originated in Asia and Africa but grows well in both tropical and subtropical environments (Paton et al., 1999). Scientific interest in basil reflects its intense use in folk medicine, and studies have reported its essential oil as having antioxidant (Jayasinghe et al., 2003), antitumor (Taie et al., 2010), and antimicrobial activities (Kaya et al., 2008), apparently due to the presence of secondary metabolic compounds such as monoterpenes (Telci et al., 2006), linalool, and eugenol, which have been intensively studied, as well as flavonoids (Taie et al., 2010).

There are currently more than thirty species of $O$. basilicum cataloged in subtropical and tropical countries (Vieira and Simon, 2006). Purple basil 'red rubin' is an O. basilicum cultivar with pink flowers and purple stalks and leaves (Simon et al., 1999). Due to its nutraceutical and pharmacological properties, purple basil has significant economical potential. Much information is still lacking concerning this cultivar, however, ranging from effective cultivation techniques to sophisticated biotechnological assays. In terms of the genus Ocimum, production processes for extracting its essential oils are of great interest, especially to the cosmetics industry (Kéita et al., 2001).

Micropropagation is an in vitro technique that enables rapid and large-scale plant propagation and development, free from diseases, while occupying only small cultivation spaces (Cheruvathur et al., 2015). With respect to the genus Ocimum, micropropagation ensures rigid control of cultivation conditions (especially environmental) as high (above $30^{\circ} \mathrm{C}$ ) or low temperatures (below $16^{\circ} \mathrm{C}$ ) in the field can cause oxidation of leaves (Shafran et al., 2007) and provoke variations in the amounts and compositions of its essential oils - with consequent production losses. Large scale micropropagation would represent an alternative and reliable 
source of raw materials for the food and cosmetic industries (Cheruvathur et al., 2015). Micropropagation is possible with many Ocimum species, such as the common green cultivar and Ocimum gratissimum (popularly known as clove basil); but other experiences are still inconclusive (Kintzios et al., 2004; Saha et al., 2012).

Each plant species requires a particular micropropagation protocol for successful reproduction. According to Rodrigues et al. (2013), plants cultivated in vitro demonstrate specific nutritional mineral demands that are determinant for optimal cell and tissue growth. There are currently no micropropagation protocols available for the 'red rubin' basil cultivar that would support breeding programs or the in vitro production of secondary metabolites through callus production or plant regeneration (Ekmekci and Aasim, 2014).

Investigations of plants of the Lamiaceae family have demonstrated that 50\% Murashige and Skoog salt levels are most appropriate for the development of species such as Pogostemon cablin Benth. (Kumaraswamy and Anuradha, 2010) and Menthas picata L. (Fadel et al., 2010). Sucrose is widely used as a source of carbon due to its ease of uptake, metabolism, and energy transformation (Kühn and Grof, 2010; Yaseen et al., 2013). The common sucrose dosage of $3 \%$ can sometimes be replaced by concentrations of 6 to $9 \%$, as many species develop better in carbon-rich media (Torres et al., 2005; Jo et al., 2009).

Similarly, activated charcoal (AC) is commonly supplied to culture media to adsorb compounds that can cause oxidation and cell death, principally phenolic compounds that can directly oxidize plant tissues or combine to form other toxic substances (Abogadallah et al., 2010; Zhang et al., 2016). AC can also adsorb substances essential to plant development, however, such as vitamins, growth regulators, and micronutrients (especially $\mathrm{Zn}$ and $\mathrm{Cu}$ ) (Hua et al., 2009).

In preliminary tests, potassium iodide (KI) was shown to accelerate plant development when added to MS medium. Potassium is one of the most abundant macronutrients in plants, acting in tropism responses, as an osmotic regulator, and contributing to the uptake of carbon and other nutrients by the root sand their distributions to other regions of the plant (Ramage and Williams, 2002).

P.cablin, a species belonging to the Family Lamiaceae, showed 93\% rooting when grown in a half dosage of MS salts and $100 \mathrm{mg} / \mathrm{L}$ activated charcoal (Kumaraswamy and Anuradha, 2010; Swamy et al. 2014). Seedlings of $O$. basilicum, a common green variety, developed well, without callus formation, in a medium enriched with $1 \mathrm{mg} / \mathrm{L}$ polyvinyl pyrrolidone (PVP) and $3.0 \mathrm{mg} / \mathrm{L}$ activated charcoal (Ekmekci and Aasim, 2014).

As such, when well balanced, these compounds can contribute to better plant development and reduced production costs, as well as improve raw material quality (Morais et al., 2012). Based on this information, we sought to assess the effects of different concentrations of mineral salts, charcoal, sucrose, and potassium on the in vitro development of $O$. basilicum red rubin.

\section{Results and Discussion}

\section{Test 1: Effects of the MS salts on the growth of purple basil}

The cultivation period lasted for 88 days, until the first plants that had germinated were well-developed. Seed germination occurred after 8 to 15 days in the control treatment ( $0 \%$ MS). Seedling oxidation was mainly observed in the control treatment (Fig 1A), probably reflecting the absence of any salts in the culture medium (Reis et al., 2008).
Statistical analyses showed differences in root and aerial portion lengths, the fresh masses of the aerial and root portions, as well as in the dry masses of the root ( $p \leq 0.05)$.No statistical differences were observed between the numbers of leaves, numbers of shoots, or oxidation $(\%)$. A linear model was used for the analyses of the aerial portion length as the means increased with increasingly nutrient levels, up to $100 \%$ (Fig 2A). A quadratic regression model was used for the analyses of root lengths. The root length averages were observed to increase with increasingly mineral salt levels, up to $69.83 \%$ (when the shoots reached approximately $85 \mathrm{~mm}$ in length); after that point, root length began to decrease (Fig 2B).

A linear model was also used for the analyses of the fresh masses of the aerial portions, when $2 \mathrm{~g}$ was obtained up to $100 \%$ of salts (Fig 2C). A quadratic regression model was used for the analyses of the fresh masses of the roots. The highest averages were observed at a MS level of $85.91 \%$, decreasing after that (Fig 2D). Quadratic regression was also the best fitting model for evaluating the dry masses of the roots; the highest averages were observed at a $85.33 \% \mathrm{MS}$ concentration (Fig 2E), a value very close to that of the highest fresh mass of the aerial portion.

Our results indicated that MS medium in the $70-85 \%$ range was most appropriate for root formation. This differed from the results of Fadel et al. (2010), who reported greater numbers of roots at a $50 \%$ MS salt concentration with Menthas picata L., while a $25 \%$ MS concentration had an inhibitory effect on root formation. Kumaraswamy and Anuradha, (2010) and Swamy et al. (2014) reported similar results with $P$. cablin (the $O$. basilicum family). Dahab et al. (2005) obtained greater numbers of roots in Ruscus poglossum L. at a 50\% MS concentration combined with 2.0 $\mathrm{mg} / \mathrm{L} \mathrm{AIB}$, and longer roots at a $25 \%$ MS concentration combined with $3.0 \mathrm{mg} / \mathrm{L}$ AIB.

Increases in root formation may be related to several isolated or combined factors that interact with the plant metabolic system, triggering specific feedbacks (Roycewicz and Malamy, 2012). Among the factors indicated as capable of influencing root development are: the osmotic potential of the culture medium, synergy or antagonist interactions among the ions in solution, and root sensibility to mineral salts (George et al., 2008; Roycewicz and Malamy, 2012).

Studies have demonstrated that when MS salt concentrations are halved, species of the Lamiaceae family show increases in root numbers and sizes (Fadel et al., 2010; Kumaraswamy and Anuradha, 2010; Swamy et al., 2014). MS medium has a high osmotic potential due its salt and sucrose concentrations (George et al., 2008), and when salt concentrations are reduced the osmotic potential likewise decreases, which contributes to more efficient water absorption by the roots. When the osmotic potential of the medium is high, root initials or root cells may not be capable of absorbing sufficient water, resulting in limited growth. We did not measure the osmotic potential of the medium, although this hypothesis could explain the greater root formation observed in $O$. basilicum red rubin, as sensitivity to physiological processes is considered a strategic reflex of plants to deal with water availability in the environment.

It has been demonstrated that other plant species (not belonging to the genus Ocimum) require low mineral salt concentrations for root development (Erig et al. 2004; Leitzke et al. 2009; Ferrari et al., 2016), such as 75\% MS concentrations (Erig et al. 2004; Leitzke et al. 2009). As roots are in direct contact with dissolved ions, they are probably subject to more osmotic stress, in addition to synergism and antagonistic effects. When synergism occurs, the presence 
Table 1. Effects of different levels of activated charcoal on $O$. basilicum 'red rubin' seedlings. The mean values of the number of shoots (NS), number of leaves (NL), oxidation (OX), aerial portion length (APL), fresh mass of the aerial portion (FMAP), dry mass of the aerial portion (DMAP), and callus (C) are presented.

\begin{tabular}{lllllll}
\hline $\begin{array}{l}\text { Activated } \\
\text { Charcoal }(\mathrm{g} / \mathrm{L})\end{array}$ & NL & OX $(\%)$ & APL $(\mathrm{mm})$ & FMAP $(\mathrm{g})$ & DMAP $(\mathrm{g})$ & C $(\%)$ \\
\hline 0.0 & $6.22 \pm 11.91^{\mathrm{b}^{\mathrm{*}}}$ & $0.00 \pm 0.00^{\mathrm{b}}$ & $17.01 \pm 33.52^{\mathrm{b}}$ & $0.30 \pm 0.58^{\mathrm{b}}$ & $0.02 \pm 0.05^{\mathrm{b}}$ & $100.00 \pm 0.00^{\mathrm{a}}$ \\
3.0 & $21.43 \pm 25.03^{\mathrm{a}}$ & $45.00 \pm 47.17^{\mathrm{a}}$ & $51.73 \pm 43.20^{\mathrm{ab}}$ & $0.66 \pm 0.73^{\mathrm{ab}}$ & $0.07 \pm 0.07^{\mathrm{ab}}$ & $0.00 \pm 0.00^{\mathrm{b}}$ \\
4.5 & $24.11 \pm 18.41^{\mathrm{a}}$ & $15.00 \pm 32.02^{\mathrm{ab}}$ & $65.81 \pm 45.46^{\mathrm{a}}$ & $1.28 \pm 0.82^{\mathrm{a}}$ & $0.13 \pm 0.08^{\mathrm{a}}$ & $0.00 \pm 0.00^{\mathrm{b}}$ \\
\hline
\end{tabular}

* Number of observations $\mathrm{N}=10^{*}$ Analysis using the Kruskal Wallis test $(\mathrm{OX})$ Test value $=3.87 \mathrm{p}(0.05)=5.990 ;(\mathrm{NB})$ Test value $=1.375 \mathrm{p}(0.05)=5.990 ;$ and $(\mathrm{NF})$ Test value $=8.865 \mathrm{p}(0.05)=5.990 *$ Other features: Average numbers followed by the same letter in the same column do not differ from each other by Tukey test at a $5 \%$ probability level.

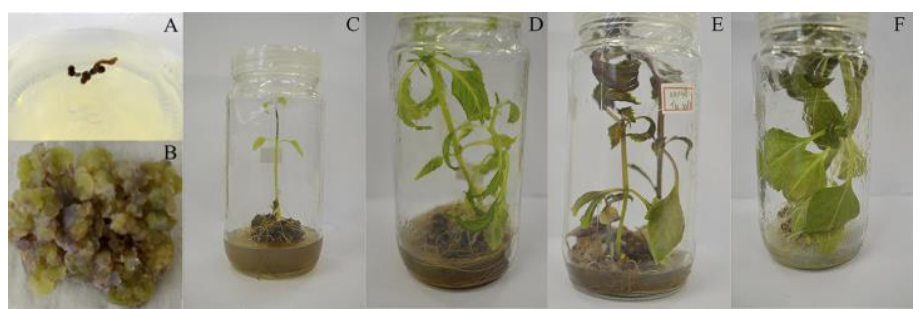

Fig 1. Effect of MS salt levels on Ocimum basilicum seedling growth. A- 0\% MS medium. B- Callus formation. C- 25\% MS medium. D- 50\% MS medium. E- 75\% MS medium. F- 100\% MS medium.

Table 2. Effects of zinc $(\mathrm{Zn})$ and copper $(\mathrm{Cu})$ accumulation on the leaves and stems of Ocimum basilicum 'red rubin' grown in media with different concentrations of charcoal and sucrose.

\begin{tabular}{|c|c|c|c|c|}
\hline $\mathrm{Zn}\left(\mathrm{mg} / \mathrm{kg}^{-1}\right)$ & & & $\left.\mathrm{mg} / \mathrm{kg}^{-1}\right)$ & \\
\hline Sucrose & & & ose & \\
\hline Charcoal & $30 \mathrm{~g} / \mathrm{L}$ & $60 \mathrm{~g} / \mathrm{L}$ & $30 \mathrm{~g} / \mathrm{L}$ & $60 \mathrm{~g} / \mathrm{L}$ \\
\hline $0 \mathrm{~g} / \mathrm{L}$ & $176.00 \pm 1.00^{\mathrm{aA}^{*}}$ & $190.50 \pm 0.50^{\mathrm{aA}}$ & $5.75 \pm 0.25^{\mathrm{bB}}$ & $9.00 \pm 0.00^{\mathrm{aA}}$ \\
\hline $3.0 \mathrm{~g} / \mathrm{L}$ & $172.25 \pm 0.25^{\mathrm{aA}}$ & $124.00 \pm 3.50^{\mathrm{bB}}$ & $8.50 \pm 0.50^{\mathrm{aA}}$ & $9.25 \pm 0.25^{\mathrm{aA}}$ \\
\hline $4.5 \mathrm{~g} / \mathrm{L}$ & $135.50 \pm 0.50^{\mathrm{aB}}$ & $86.50 \pm 0.5^{\mathrm{bC}}$ & $5.50 \pm 0.00^{\mathrm{aB}}$ & $5.75 \pm 0.25^{\mathrm{aB}}$ \\
\hline
\end{tabular}
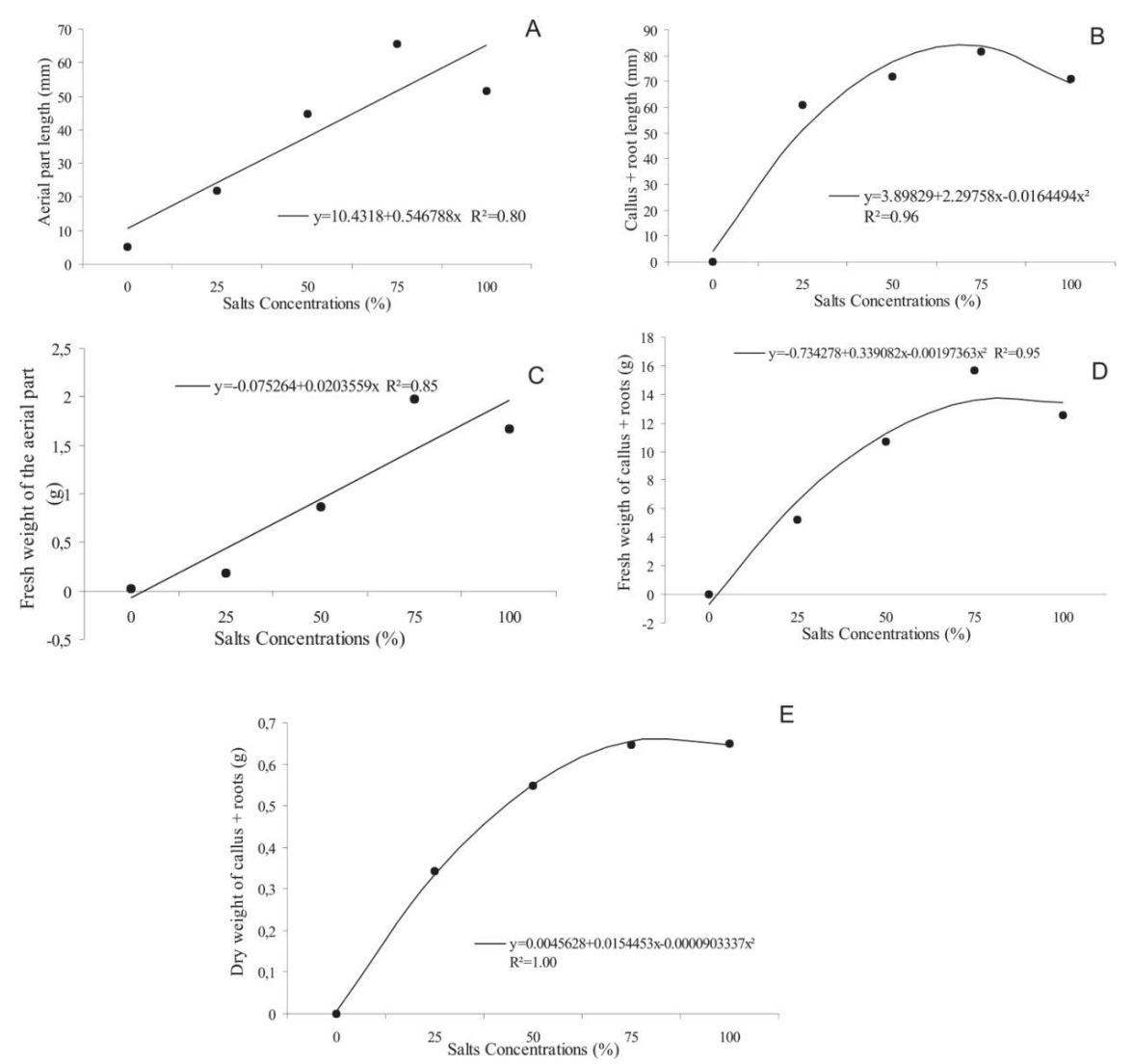

Fig 2. Effects of MS salt concentrations on shoot length (A), root length (B), fresh mass of the aerial portion (C), fresh mass of callus and root (D), and dry mass of callus and root (E), of O. basilicum seedlings cultivated in vitro. 


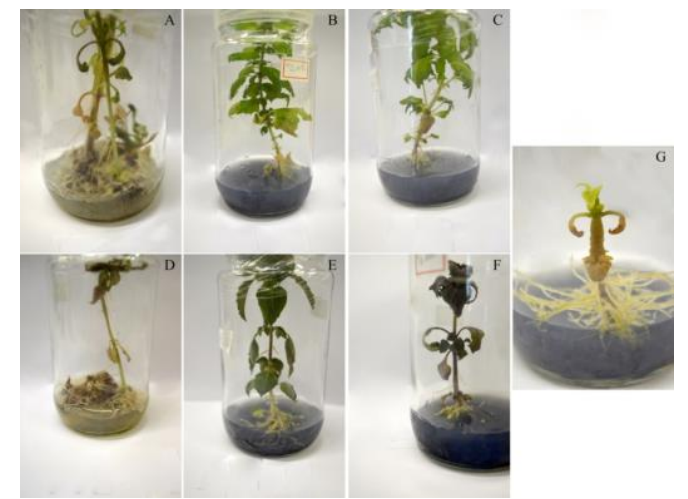

Fig 3. Effects of different concentrations of activated charcoal and sucrose on the lengths of $O$. basilicum seedlings: A- $30 \mathrm{~g} / \mathrm{L}$ SUC and $0 \mathrm{~g} / \mathrm{L} \mathrm{AC} ; \mathrm{B}-30 \mathrm{~g} / \mathrm{L}$ SUC and $3.0 \mathrm{~g} / \mathrm{L} \mathrm{AC} ; \mathrm{C}-30 \mathrm{~g} / \mathrm{L}$ SUC and $4.5 \mathrm{~g} / \mathrm{L} \mathrm{AC} ; \mathrm{D}-60 \mathrm{~g} / \mathrm{L}$ SUC and $0 \mathrm{~g} / \mathrm{L} \mathrm{AC} ; \mathrm{E}-60 \mathrm{~g} / \mathrm{L} \mathrm{SUC}$ and $3.0 \mathrm{~g} / \mathrm{L} \mathrm{AC} ; \mathrm{F}-60 \mathrm{~g} \mathrm{~g} / \mathrm{L}$ SUC and $4.5 \mathrm{~g} / \mathrm{L} \mathrm{AC} ; \mathrm{G}-$ Abnormal Seedling.

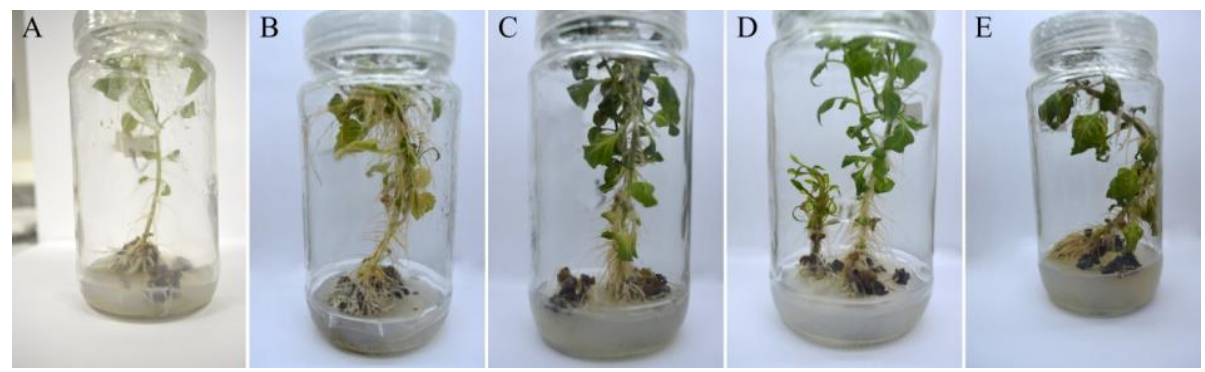

Fig 4. Effect of different levels of KI on the seeds of $O$. basilicum.A - $0 \mu \mathrm{M} ; \mathrm{B}-25 \mu \mathrm{M}$; C-50 $\mu \mathrm{M}$; D - $75 \mu \mathrm{M} ; \mathrm{E}-100 \mu \mathrm{M}$.
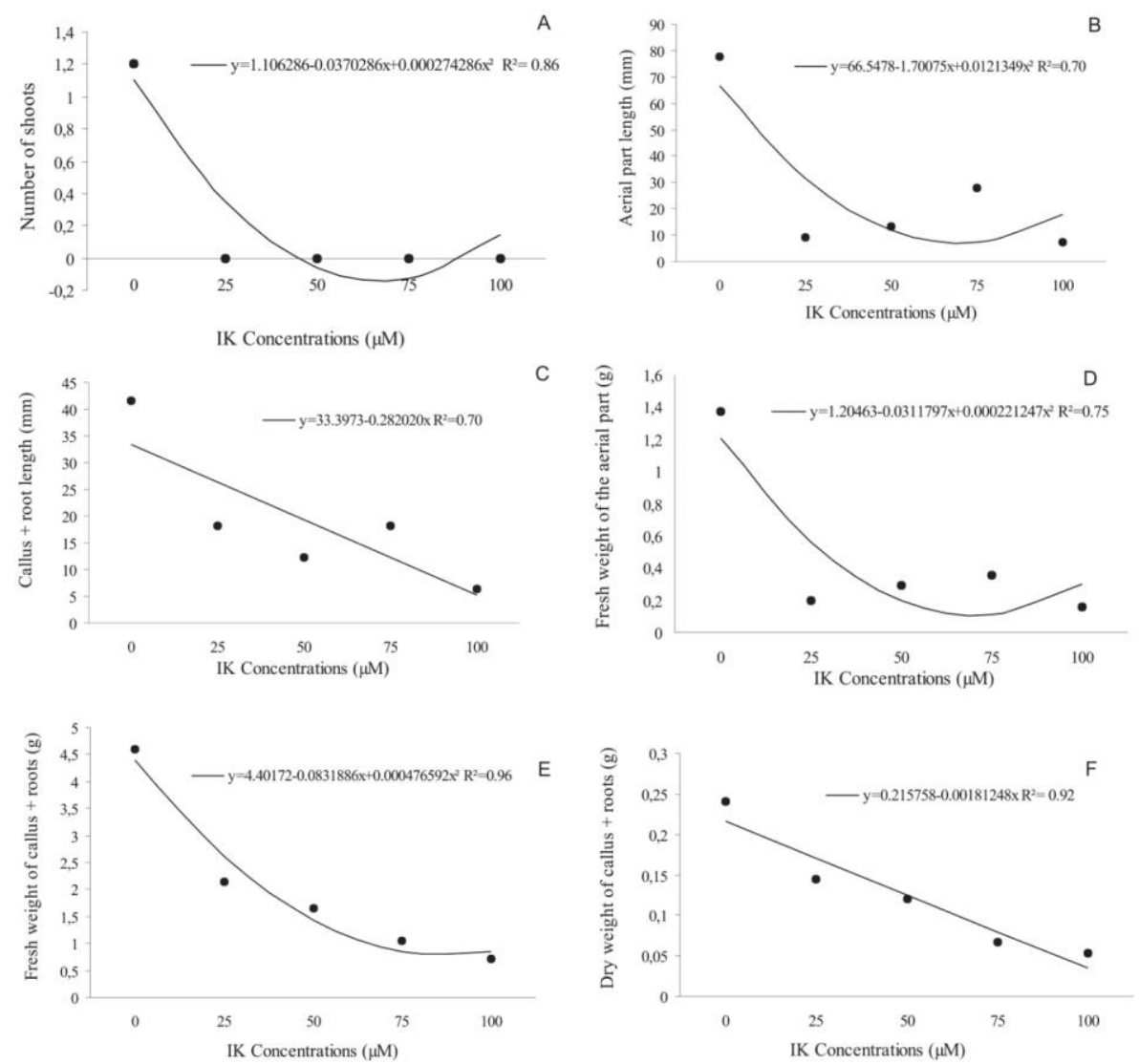

Fig 5. Effects of KI concentrations on the number of shoots (A), aerial portion length (B), root length (C), fresh mass of the aerial portion (D), fresh mass of the roots (E), and dry mass of the roots (F) of O. basilicum. 

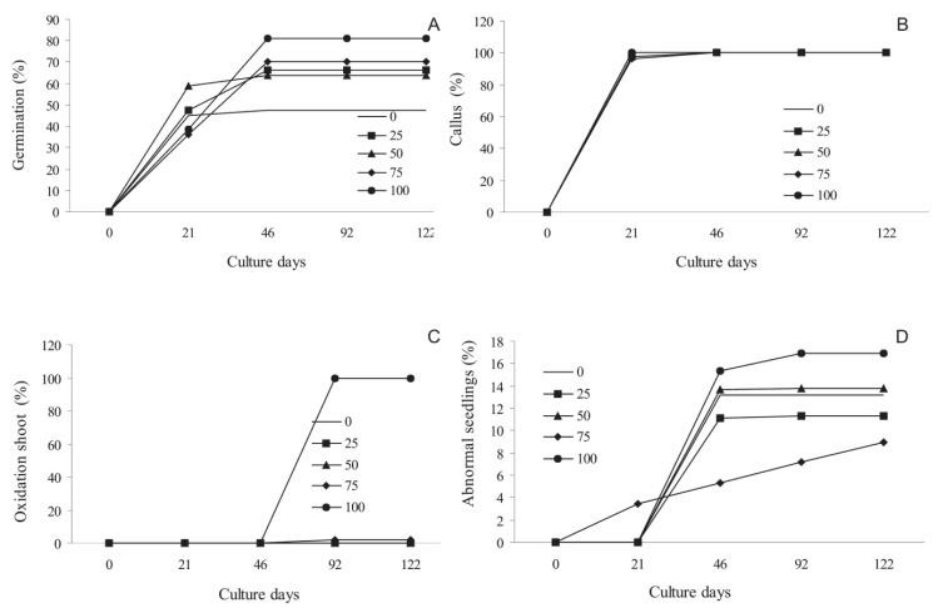

Fig 6. Effects of different KI concentrations on germination (\%) (A), callus formation (\%) (B), oxidized plants (\%) (C), and abnormal plants (\%) (D), of Ocimum basilicum'red rubin'.

and concentrations of certain ions can favor the absorption of other ions by the roots; antagonistic effects occur when one type of ion competes with another for the same absorption site, limiting its uptake (Silvia and Trevizam, 2015). According to George et al. (2008), high phosphate concentrations can reduce the absorption of $\mathrm{Zn}, \mathrm{Fe}$, and $\mathrm{Cu}$, while high concentrations of $\mathrm{K}^{+}$or $\mathrm{Ca}^{2+}$ and $\mathrm{Mg}$ can decrease the absorption of phosphate in slightly alkaline solutions, thus hindering root growth.

In relation to the development of the aerial portion of the plant, higher fresh mass accumulations have been reported with low mineral salt availabilities. This appears to occur because certain nutrients cause negative effects on plant growth at high concentrations. Absorption rates may exceed utilization rates in in vitro environments, and effect that does not occur in vivo (Ramage and Williams, 2002; Silva et al., 2016). Shoot lengths and shoot masses showed high values at $100 \%$ MS salt concentrations, probably reflecting their high demands (principally) for nitrogen, a key component of proteins and nucleic acids (George et al., 2008). Our findings also corroborated the results of Ribeiro et al. (2007), who reported that $100 \%$ MS salts benefited shoot growth in purple basil.

Callus formation was observed in all treatments, with some being friable and others not (Fig 1B). The root system was observed to develop first, followed by the aerial portion of the seedling (Fig 1C). In general, plants originating from calluses had abnormal appearances, with thin stems and no leaves (Fig 1C). This may reflect the presence of compounds that can hinder the plant growth that were secreted into the culture medium during callus formation (such as phenols) (Dalponte et al., 2009; Artioli-Coelho et al., 2015). In the present study, callus formation was apparently caused by the presence of growth regulators (BAP) in dosage above those required for normal plant metabolism (Sáenz et al., 2010).

\section{Test 2: Effects of charcoal and sucrose on the growth of purple basil}

For these tests, the plants were kept in the growth chamber for up to 91 days. Seeds germinated at 10-35 days. Final evaluations showed there was no evidence of interactions between sucrose and activated charcoal concentrations $(p \leq 0.05)$ in terms of any of the growth parameters evaluated. The isolated action of activated charcoal was observed in terms of the numbers of leaves, oxidized plants, aerial portion length, fresh mass of the aerial portion, dry mass of the aerial portion, and callus percentage.

The absence of activated charcoal had a negative effect on the number of leaves, seedling oxidation percentage, aerial portion length, and dry and fresh mass of the aerial portion (Table 1). The number of leaves, aerial portion length, and fresh and dry mass of the aerial portion were benefited by activated charcoal at $4.5 \mathrm{~g} / \mathrm{L}$ (Table 1 ).

Although activated charcoal may absorb elements that can damage plants, it can also absorb beneficial nutrients and promote the elongation and multiplication of the aerial portions of plants (Thomas, 2008). Biomass production has been reported as being favored by the adsorption of harmful compounds present in the medium, principally phenols, thus benefiting the development of the aerial portion of the plant (Thomas, 2008; Gautam et al., 2014). Charcoal is commonly used in tissue culture procedures, and Ekmekci and Aasim (2014) reported greater growth of the aerial portion and enhanced rooting of $O$. basilicum with charcoal and polyvinyl pyrrolidone (PVP) added to the MS medium. For species of the same family as basil, antioxidant substances added to the culture medium have been observed to favor seedling development, principally activated charcoal and PVP (Kumaraswamy and Anuradha, 2010; Swamy et al., 2014)

The presence of callus was observed in $100 \%$ of the seedlings that developed in MS medium without charcoal (Fig $3 \mathrm{~A}$ and $\mathrm{D}$ ), indicating that charcoal was essential to diminishing callus formation. This result indicates that callus formation in 'red rubin' basil is related to increased uptakes of metals (such as copper) from the media that can generate free radicals that cause stress (Posmyk et al., 2009). The formation of callus can also be influenced by growth regulators adhering to the activated charcoal (Thomas, 2008; Sáenz et al., 2010). These factors, together with the sensitivity of $O$. basilicum red rubin, are the probable causes of those abnormalities (Fig 3A and D).

Curved leaves with sickle-like appearances were observed in seedlings growing in medium with $60 \mathrm{~g} / \mathrm{L}$ sucrose plus 4.5 $\mathrm{g} / \mathrm{L}$ activated charcoal (Fig 3F). According to Yruela, (2005) those leaf abnormalities can occur as responses to both deficiencies and excesses of $\mathrm{Cu}^{+}$ions; $\mathrm{Cu}$ deficiencies cause leaf folding, while excess $\mathrm{Cu}$ causes the formation of hydroxyl radicals that can increase plant oxidation and cause permanent damage to its DNA. We observed that plants with foliar deficiencies had smaller accumulations of $\mathrm{Cu}^{+}$in their aerial portions (Table 2). 
Higher percentages of plant oxidation (45\%) were observed with $3.0 \mathrm{~g} / \mathrm{L}$ of activated charcoal. A reduction in oxidized seedlings $>30 \%$ was observed at activated charcoal concentrations of $4.5 \mathrm{~g} / \mathrm{L}$ (Table 1 ). $\mathrm{Zn}$ and $\mathrm{Cu}$ are essential elements for plants, but both have great affinities for organic molecules; $\mathrm{Cu}$ in large quantities, for example, can undergo reactions in plants and release free radicals (Clemens et al., 2002; Yruela, 2005). This could explain the high oxidation rate (Table 1) observed in plants grown in medium with 30 $\mathrm{g} / \mathrm{L}$ sucrose and $3.0 \mathrm{~g} / \mathrm{L}$ activated charcoal (Table 2).

Interactions between activated charcoal and sucrose affected $\mathrm{Zn}$ and $\mathrm{Cu}$ accumulations in the aerial portions of the plants ( $\mathrm{p} \leq 0.05$ ). The lowest $\mathrm{Zn}$ content encountered was $86.50 \mathrm{mg} / \mathrm{kg}^{-1}$ with seedlings grown in a combination of 60 $\mathrm{g} / \mathrm{L}$ sucrose and $4.5 \mathrm{~g} / \mathrm{L}$ activated charcoal. This represents $50.85 \%$ less $\mathrm{Zn}$ in the leaves and stalks as compared to control plants. The highest measured concentration of $\mathrm{Zn}$ was $190.50 \mathrm{mg} / \mathrm{kg}^{-1}$ when seedlings were grown in $60 \mathrm{~g} / \mathrm{L}$ sucrose and $0 \mathrm{~g} / \mathrm{L}$ charcoal (Table 2). These results indicate that the highest sugar concentration without activated charcoal increased $\mathrm{Zn}$ assimilation. The opposite occurred in the presence of activated charcoal, as higher AC concentrations appear to hinder $\mathrm{Zn}$ assimilation by leaves and stems. This corroborates Thomas (2008) and Awoyale et al. (2013), who reported that activated charcoal adsorbs metallic ions, especially zinc and copper.

When high concentrations of sucrose and $3.0 \mathrm{~g} / \mathrm{L}$ of activated charcoal (Table 2) were used in the media, plant copper levels remained elevated. Reductions in copper assimilation were observed with $4.5 \mathrm{~g} / \mathrm{L}$ charcoal, independent of the sucrose concentration used (Table 2). These results indicate that there is a relationship between sucrose and copper. Dugas and Bartel (2008) reported the existence of two gene families in Arabidopsis (CSD1 and CSD2) that regulate the production of superoxide dismutase (SOD) that contains $\mathrm{Cu}$. This enzyme is activated when plants are exposed to UV light or oxidative stress, or other stress factors (Yruela, 2005). CSD1 and CSD2 genes are also regulated by micro RNAs (miRNAs), specifically (miR398). If the sucrose concentration in the medium is high, miR398 accumulation occurs and CSD1 and CSD2 expressions decrease significantly (as well copper use). Curiously, our findings demonstrated that under high concentrations of sucrose and in the absence of charcoal (or at minimum doses), plant copper levels were high. Therefore sucrose concentrations appear to influence copper accumulation by plants, and likewise appear to positively influence $\mathrm{Zn}$ uptake and accumulation. This would help explain the relationship between sucrose and copper, although follow-up studies will be needed to confirm this observation.

$\mathrm{Zn}$ deficiencies in plants reduce enzymatic activities that are important to metabolic processes, particularly DNA replication and transcription processes and, in some cases, IAA synthesis. Morphologically, plants with $\mathrm{Zn}$ deficiencies produce small leaves (Malta et al., 2002). Cu deficiencies hinder the activities of some enzymes necessary for the oxidation and hydroxylation of phenolic components (Yruela, 2005; Posmyk et al., 2009). Those limitations apparently were not strong enough to cause major damage to the growth of $O$. basilicum red rubin seedlings, as their growth in media with activated charcoal $(4.5 \mathrm{~g} / \mathrm{L})$ was more pronounced than the control group (Table 1). Plants with short internodes and small leaves were not observed in these treatments (Fig 3 B, $\mathrm{C}$ and $\mathrm{E}$ ), only common symptoms of copper deficiency, such as curved leaves with sickle-like appearances (Fig 3 F).

\section{Test 3: KI effects on the growth of purple basil}

The addition of $\mathrm{K}$ appeared favorable to the development of this species in pre-tests. Cultivation in the growth chamber lasted for 99 days, with seed germination occurring between days 7 and 35. After germination, the seeds differentiated into small calluses, and then the roots and aerial portions developed (Fig 4). Statistical differences ( $\leq 0.05)$ were observed in terms of the numbers of shoots, aerial portion length, root and callus length, fresh mass of the aerial portion, fresh mass of callus and root, and dry mass of callus and root among the different KI concentrations (Figure 5); the number of leaves, dry mass of the aerial portion, oxidation, and callus percentages did not differ statistically under those conditions. A quadratic regression model was used for the analyses of the numbers of shoots. No shoots were observed in the presence of $67.45 \mu \mathrm{M}$ potassium iodide (KI). Above this $\mathrm{KI}$ concentration, plants developed normally (Fig 5A). Ahire et al. (2014) reported that salt stress in plants will affect plant development and growth. Surplus K appeared to cause stress that affected not only the number of shoots but also the growth of the aerial portion.

The best fit for the analysis of aerial portion length (APL) was a quadratic regression model. We observed growth of approximately $10 \mathrm{~mm}$ when exposed to KI concentrations up to $70.08 \mu \mathrm{M}$, which was $60 \mathrm{~mm}$ less than the control group (Fig 5B). Potassium affects plant growth and cell metabolism (Wang et al., 2013), and at toxic levels it will inhibit the development of the aerial portion (Ahire et al., 2014). The root length data fitted a linear model, and decreased by approximately $30 \mathrm{~mm}$ at increasing $\mathrm{K}$ concentrations, from 0 to $100 \mu \mathrm{M} \mathrm{KI}$ (Fig 5C).

It is known that increased $\mathrm{K}^{+}$concentrations in the medium can influence the uptake of other nutrients, which may lead to deficits of magnesium $(\mathrm{Mg})$ and calcium $(\mathrm{Ca})$ and hamper plant development (Andriolo et al., 2010). The $\mathrm{K}^{+}$ concentration in $100 \%$ MS medium may, in itself, be sufficient for the needs of this basil variety, so that complementing it was not necessary. Surplus $\mathrm{K}^{+}$can influence vital plant processes as potassium activates various enzymes and is involved in membrane transport and osmoregulation (Wang et al., 2013).

The fresh mass of the aerial portion and of the callus plus roots (FMAP; FMCR) fitted a quadratic regression model. The lowest FMAP value (approx. 0.2g) was observed at $70.54 \mu \mathrm{M}$ KI (Fig 5D). Increased levels of $\mathrm{K}^{+}$may cause several problems for plants, including competition for nutrients (Shabala and Cuin, 2007; Andriolo et al., 2010) and damage to cell plasma membranes due to homeostatic imbalances - resulting in decreased plant growth (Ahire et al., 2014).

The fresh mass of callus plus roots showed the lowest values at $87.29 \mu \mathrm{M} \mathrm{KI}$; above that $\mathrm{KI}$ concentration, seedlings fresh biomasses increased (Fig 6E). The dry mass of callus plus roots decreased with increasing $\mathrm{K}$ concentrations up to $100 \mu \mathrm{M} \mathrm{KI}$ (Fig 6F). Alves et al. (2016) tested the effects of different concentrations of potassium silicate on Cattleya loddigesiie, and observed decreasing root fresh mass values at high doses, probably due to water uptake difficulties due to those salts, resulting in alterations of plant biomass.

Figure 6 shows the effect of KI on seed germination, callus formation, plant oxidation, and plant abnormalities. The addition of $100 \mu \mathrm{M}$ KI to the medium favored a germination rate of approximately $80 \%$ (Fig 6A). Potassium nitrate has been used to improve seed germination, with increases of up to 50\% (Çetinbaş and Koyuncu, 2006; Bian et al., 2013). 
There is currently no evidence of the isolated promotion of germination by potassium; potassium does, however, enable metabolic and biochemical reactions, thus favoring seed germination (Zavariyan et al., 2015). The germination rate tended to decrease at $\mathrm{K}$ concentrations below $50 \mu \mathrm{M} \mathrm{KI}$ as compared to the control. All samples showed callus formation (Fig 4B) until the end of the last complementary analysis (Fig 4 A, B, C, D and E).

Oxidized seedlings appeared after 35 days (Fig 6C) until the last day of cultivation when exposed to KI concentrations of $100 \mu \mathrm{M}$. The other treatments showed only slight oxidation rates. This may have occurred because surplus potassium influences calcium absorption, and the latter mineral is important for the production of superoxide enzymes for antioxidant action (Valmorbida et al., 2007; Chao et al., 2009) and is a critical component of the plant cell wall, so that calcium deficiencies are principally observed in young leaves as it is not transported in the phloem. The lowest abnormality rate $(9 \%)$ was observed at $75 \mu \mathrm{M}$ KI. The highest abnormality rate $(18 \%)$ was seen at $100 \mu \mathrm{M} \mathrm{KI}$, probably due to high competition between $\mathrm{Ca}$ and $\mathrm{Mg}$ for absorption sites and imbalances in the uptake and distribution of nutrients essential to full plant development (Chao et al., 2009; Andriolo et al., 2010). Although the highest percentage of abnormal plants was observed at $100 \mu \mathrm{M} \mathrm{KI}$, other KI levels, such as $75 \mu \mathrm{M}$, also caused plant abnormalities as compared to the control group. This can be explained by the influence of BAP and NAA on the formation of abnormal seedlings (Lédo et al., 2008).

Red rubin basil showed different growth responses according to different alterations of its culture medium, and thus seems to be more sensitive than other Ocimum cultivars. Our findings demonstrated the influences of MS salt concentrations on the development of the aerial portion of red rubin, with MS medium at full strength showing the maximum potential for promoting vigorous seedling growth. In contrast, root development was limited by full strength MS, showing improved development only at lower salt concentrations. Similarly, a sucrose concentration of $30 \mathrm{~g} / \mathrm{L}$ was found to result in better growth of the red rubin basil variety than the standard the $60 \mathrm{~g} / \mathrm{L}$.

One difficulty encountered in this study was related to the formation of callus under almost all experimental conditions. Callus formation is required on some occasions for some species, mainly related to organogenic regeneration processes. It would be energetically more favorable, however, if the plant could avoid expending its energy on callus formation and concentrate instead on the production of aerial portions and roots. Callus can also release toxic substances that affect plant development. This problem is usually resolved by the addition of activated charcoal, as in the present study. It was possible to demonstrate that charcoal has the capacity to adsorb certain metals, principally copper and zinc, although this was not sufficient to totally avoid the impaired development of red rubin basil.

Another difficulty encountered was the incidence of abnormal seedlings (discussed above according to the different treatments), making it necessary to take into consideration other factors related to the culture medium, mainly interactions between medium constituents and endogenous and exogenous growing regulators. This was an initial difficulty in growing these seedlings in vitro, as there were no specific reports in the literature concerning cultivation recommendations for this plant, so that future studies on the effects of growth regulators should be considered.
Finally, the addition of extra potassium to the culture medium (which pre-tests had indicated to be beneficial to seedling development) was not found to have positive effects on the phytotechnical characteristics analyzed here, except for seed germination (which was increased by exposure to high potassium concentrations). Thus, other methods should be tested to increase germination, such as additions of gibberellins to the culture media, or physical treatments.

\section{Materials and Methods}

\section{Plant material}

The present work was conducted at Laboratory of Tissue Culture and Plant Molecular Biology at the Paranaense University (UNIPAR), Parana State, Brazil. The seeds of $O$. basilicum red rubin (100\% purity and $79 \%$ germination) used here were purchased from ISLA ${ }^{\circledR}$.

\section{Sterilization of seeds}

O. basilicum red rubin seeds were disinfected in a $70 \%$ alcohol solution for 2 minutes (in a laminar air flow chamber) followed by immersion in a $2 \%$ hypochlorite solution $\left(\mathrm{v} \mathrm{v}^{-1}\right)$ for 20 min., with subsequent rinsing four times in sterilized deionized water. The seeds were maintained immersed in 5 $\mathrm{ml}$ of sterile water until used. This same procedure was employed in all trials.

\section{Test 1: Effects of MS Salts}

After sterilization, the seeds were inoculated into $350 \mathrm{ml}$ transparent glass vials containing $50 \mathrm{ml}$ of different concentrations $(0,25,50,75$ and $100 \%)$ of MS medium (Murashige and Skoog, 1962); two growth regulators (0.5 $\mu \mathrm{M}$ benzylaminopurine [BAP] and $1.0 \mu \mathrm{M}$ naphthalene acetic acid [NAA]), $30 \mathrm{~g} / \mathrm{L}$ sucrose, and $6.6 \mathrm{~g} / \mathrm{L}$ agar (Kasvi ${ }^{\circledR}$ ) were also added, with the $\mathrm{pH}$ adjusted to 5.8 .

\section{Test 2: Effects of Charcoal and Sucrose}

Two different concentrations of sucrose (30 and $60 \mathrm{~g} / \mathrm{L}$ ) combined with three concentrations of activated charcoal (AC) $(0,3.0$, and $4.5 \mathrm{~g} / \mathrm{L})$ dissolved in $100 \%$ MS medium were evaluated (with the addition of growth regulators 0.5 $\mu \mathrm{M}$ benzylaminopurine [BAP] and $1.0 \mu \mathrm{M}$ naphthalene acetic acid [NAA]) with $6.6 \mathrm{~g} / \mathrm{L}$ agar (Kasvi $\left.{ }^{\circledR}\right)$, and the $\mathrm{pH}$ adjusted to 5.8 .

\section{Test 3: KI effect}

Five levels of potassium iodide (KI) $(0,25,50,75$ and 100 $\mu \mathrm{M}$ ) in $100 \%$ MS medium were evaluated (with the addition of growth regulators $0.5 \mu \mathrm{M}$ benzylaminopurine [BAP] and $1.0 \mu \mathrm{M}$ naphthalene acetic acid [NAA]) with $30 \mathrm{~g} / \mathrm{L}$ sucrose and $6.6 \mathrm{~g} / \mathrm{L}$ agar $\left(\mathrm{Kasvi}^{\circledR}\right)$, and the $\mathrm{pH}$ adjusted to 5.8 .

\section{Cultivation conditions and the characteristics evaluated}

Seed transfers were performed under aseptic conditions, sowing them into flasks containing $50 \mathrm{~mL}$ MS culture medium; the flasks were subsequently capped with transparent plastic lids and sealed with PVC film. All treatments were maintained in a growth chamber at $25 \pm 2{ }^{\circ} \mathrm{C}$, under a light intensity of 3600 lux provided by white fluorescent lamps (Empalux ${ }^{\circledR} 10-20 \mathrm{w}-6400 \mathrm{~K}$ ) (monitored using a Lux Meter). 
When the plants were well-developed, they were removed from the culture medium, washed in running water to remove any agar residues, and then placed on paper towels to absorb any surplus water adhering to the roots. The numbers of shoots (NS), leaves (NL), oxidized plants (OX), and the presence of callus (NC) were noted; root (RL) and aerial portion (APL) lengths recorded. Additionally, the fresh masses of the aerial portions (FMAP) and the fresh masses of the roots, or of the root + callus, (FMRC) were weighed, and then subsequently dried in an oven at $60{ }^{\circ} \mathrm{C}$ to a constant mass to calculate the dry mass of the aerial portion (DMAP) and the dry mass of the root or of the root + callus portion (DMRC). Seedling germination, seedling oxidation, as well as callus and abnormal seedlings formation were recorded 24 , 35,76 and 98 days after in vitro inoculation.

The amounts of Copper $(\mathrm{Cu})$ and Zinc $(\mathrm{Zn})$ in the leaves and stems were determined according to Malavolta et al. (1987) at the Plant Tissue Laboratory of the University of São Paulo-USP. All analyzes were performed in duplicate.

\section{Data analysis}

A completely randomized experimental design was used in all tests, with five replicates, four vials per test, and 4 seeds per vial. In Test 2 , seedling oxidation (\%) and the numbers of leaves and shoots were submitted to non-parametric analysis using the Kruskal Wallis test ( $\mathrm{p} \leq 0.05)$. The other data were submitted to analysis of variance $(\mathrm{p} \leq 0.05)$. The qualitative means were evaluated by the Tukey test $(p \leq 0.05)$, and the quantitative means by polynomial regression $(\mathrm{p} \leq 0.05)$. All analyzes were performed using computer statistical analysis system (SISVAR 5.6) software (Ferreira, 2011).

\section{Conclusion}

The MS salt concentration most indicated for the 'red rubin' cultivar was $100 \%$ complete culture medium, if the objective was aerial portion production, or $70-80 \%$ if the objective was root production. The sucrose level indicated for the best seedling development, and for suppressing callus formation, was the standard dose of $30 \mathrm{~g} / \mathrm{L}$, combined with $4.5 \mathrm{~g} / \mathrm{L}$ of activated charcoal. The addition of activated charcoal limited copper and zinc uptake by the $O$. basilicum seedlings, but did not excessively hamper their development.

The addition of potassium to the culture medium is not required for this cultivar, as the standard concentration in the medium is sufficient for plant development.

\section{Acknowledgements}

The authors thank the Brazilian Federal Agency for Support and Evaluation of Graduate Education (CAPES) for the scholarship, and the Paranaense University for all financial support.

\section{References}

Abogadallah GM, Serag MM, Quick WP (2010) Fine and coarse regulation of reactive oxygen species in the salt tolerant mutants of barnyard grass and their wild-type parents under salt stress. Physiol Plant. 138(1):60-73.

Ahire ML, Laxmi S, Walunj PR, KaviKishor PB, Nikam TD (2014) Effect of potassium chloride and calcium chloride induced stress on in vitro cultures of Bacopa monnieri (L.) pennell and accumulation of medicinally important bacoside A. J Plant Biochem Biotechnol. 23(4):366-378.
Alves GAC, Campos FR, Bertoncelli DJ, Furlan FF, Freiria GH, Faria RT (2016) Development of Cattleya loddigesii Lindley in vitro with doses of potassium silicate. Rev Agrotec.37(1):81-87.

Andriolo JL, Jänisch DI, Schmitt OJ, Picio MD, Cardoso FL, Erpen L (2010) Potassium and calcium doses on plant growth, fruit yield and quality of strawberries in soilless cultivation. Cien Rural. 40(2):267-272.

Artioli-Coelho FA, Paiva R, Silva LC, Barbosa S, Beijo LA (2015) Vitamin C and total phenols quantification in calli of native passion fruit induced by combinations of picloram and kinetin. Cien Rural. 45(8):1459-1465.

Awoyale AA, Eloka-Eboka AC, Odubiyi OA (2013) Production and experimental efficiency of activated carbon from local waste bamboo for waste water treatment. Int J Eng Appl Sci technol. 13(3):8-17.

Bian L, Yang L, Wang J, Shen $\mathrm{H}$ (2013) Effects of $\mathrm{KNO}_{3}$ pretreatment and temperature on seed germination of Sorbus pohuashanensis. J For Res. 24 (2):309-316.

Çetinbaş M, Koyuncu F (2006) Improving germination of Prunus avium L. seeds by gibberellic acid, potassium nitrate and thiourea. Hort Sci. 33(3):119-123.

Chao L, Weiqian C, Yun L, Hao H, Liang C, Xiaoqing L, Fashui $\mathrm{H}$ (2009) Cerium under calcium deficiency-influence on the antioxidative defense system in spinach plants. Plant Soil. 323:285-294.

Cheruvathur MK, Abraham J, Thomas TD (2015) In vitro micropropagation and flowering in Ipomoea sepiaria Roxb. an important ethano medicinal plant. Asian Pac J Reprod. 4(1): 49-53.

Clemens S, Palmgren MG, Krämer U (2002) A long way ahead: understanding and engineering plant metal accumulation. Trends Plant Sci. 7(7):309-315.

Dahab AMA, Habib AMA, Hosni YA, Gabr AMM (2005) Effect of MS-salt strength, sucrose and IBA concentration and acclimatization media on Ruscushy poglossum L. micropropagation. Arab J Biotech.8(1):141-154.

Dalponte F, Valle RCSC, Valle JAB (2009) Uso de adsorventes de compostos fenólicos e diferentes explantes na produção de massa celular. Dynamis Rev Tecno-Cien. 15(2):12-17.

Dugas DV, Bartel B (2008) Sucrose induction of Arabidopsis miR398 represses two $\mathrm{Cu} / \mathrm{Zn}$ superoxide dismutases. Plant Mol Biol. 67:403-417.

Ekmekci H, Aasim M (2014) In vitro plant regeneration of Turkish sweet basil (Ocimum basilicum L.). J Ani M Plant Sci. 24(6):1758-1765.

Erig AC, Schuch MW, Chaves AC (2004) In vitro rooting and acclimatization of quince scions cvs. mc and adams, used as rootstock for pear. Scientia Agraria 5:61-68.

Fadel D, Kintzios S, Economou AS, Moschopoulou G, Constantinidou HIA (2010) Effect of different strength of medium on organogenesis, phenolic accumulation and antioxidant activity of spearmint (Mentha spicata L.).Open Hort J. 7(3):31-35.

Ferrari MSP, Antoniazzi D, Nascimento AB, Franz LF, Bezerra CS, Magalhães HM (2016) Evaluation of new protocols to Curcuma Longa micropropagation: a medicinal and ornamental specie. J Med Plants Res.10:367:376.

Ferreira DF (2011) Sisvar: A computer statical analysis system. Cienc Agrotec. 35(6):1039-1042

Gautam RK, Mudhoo A, Lofrano G, Chattopadhyaya MC (2014) Biomass-derived biosorbents for metal ions sequestration: adsorbent 3 modification and activation methods and adsorbent regeneration. J Environ Chem Engin. 2(1):239-259.

George EF, Hall MA, Klerk GJ (2008). Plant propagation by tissue culture, 1rd edn. Springer, New York.

Hua L, Wu W, Liu Y, Mcbride, M. B, Chen Y (2009) Reduction of nitrogen loss and $\mathrm{Cu}$ and $\mathrm{Zn}$ mobility during sludge composting with bamboo charcoal amendment. Environ Sci Pollut Res.16:1-9. 
Jayasinghe C, Gotoh N, Aoki T, Wada S (2003) Phenolics composition and antioxidant activity of sweet basil (Ocimum basilicum L.). J Agric Food Chem. 51(15):4442-4449.

Jo E, Tewari RK, Hahn E, Park K (2009) In vitro sucrose concentration affects growth and acclimatization of Alocasia amazonica plantlets. Plant Cell Tissue Organ Cult. 96: 307-315.

Kaya I, Yiğit N, Benli M (2008) Antimicrobial activity of various extracts of Ocimum basilicum L. and observation of the inhibition effect on bacterial cells by use of scanning electron microscopy. Afr J Tradit. 5(4):363-369.

Kéita SM, Vicent C, Schmit JP, Arnason JT, Bélanger A (2001) Efficacy of essential oil of Ocimum basilicum L. and $O$. gratissimum L. applied as an insecticidal fumigant and powder to control Callosobruchus maculatus (Fab.) [Coleoptera: Bruchidae]. J Stored Prod Res.37:(4) 339-349.

Kintzios S, Kollias H, Stratouris E, Makri O (2004) Scale-up micropropagation of sweet basil (Ocimum basilicum L.) in an airlift bioreactor and accumulation of rosmarinic acid. Biotechnol Lett. 26 (6):521-523.

Kühn C, Grof CP (2010) Sucrose transporters of higher plants. Curr Opin Plant Biol.13(3): 288-298.

Kumaraswamy M, Anuradha M (2010) Micropropagation of Pogostemon cablin Benth. through direct regeneration for production of true to type plants. Plant Tissue Cult Biotechnol. 20(1):81-89.

Lédo AS, Blank AF, Barboza SBSC, Rangel MAS, Lédo CAS (2008) Germinação in vitro de embriões zigóticos e sementes de nim indiano (Azadirachta indica A. Juss.). Rev Bras Plantas Med.10(3):1-5.

Leitzke LN, Damiani CR, Schuch MW (2009) Blackberry 'xavante' in vitro multiplication and rooting: salt concentrations effect, explant type, and activated coal on culture medium. Ciên Agrotec. 33:1959-1966.

Malavolta E, Vitti GC, Oliveira SA (1987) Avaliação do estado nutricional das plantas: princípios e aplicações, 2rd edn. Potáfos, Piracicaba.

Malta MR, Neto AEF, Alves JD, Guimarães PTG (2002) Effect of zinc application on tryptophan synthesis, total amino acids and total soluble proteins of leaves of coffee seedlings. Braz J Plant Physiol.14(1):31-37.

Morais TP, Luz JMQ, Silva SM, Resende RF, Silva AS (2012) Aplicações da cultura de tecidos em plantas medicinais. Rev Bras Plantas Med.14(1):110-121.

Murashige T, Skoog F (1962) A revised medium for rapid growth and bio assays with tobacco tissue cultures. Physiol Plant. 5:473-497.

Paton A, Harley RM, Harley MM (1999) Ocimum: an overview of classification and relationships. In: Holm Y, Hiltunen R. eds. Ocimum. Medicinal and aromatic plants -industrial profiles, 1rd edn. Hardman, Harwood, Amsterdam.

Posmyk MM, Kontek R, Janas KM (2009) Antioxidant enzymes activity and phenolic compounds content in red cabbage seedlings exposed to copper stress. Ecotoxicol Environ Saf. 729(2):596-602.

Ramage CM, Williams RR (2002) Mineral nutrition and plant morphogenesis. In Vitro Cell Dev Biol.38:116-124.

Reis ES, Pinto JEB, Rosado LDS, Corrêa RM (2008) Influência do meio de cultura na germinação de sementes in vitro e taxa de multiplicação de Melissa officinalis L. Rev Ceres. 55(3):160-167.

Ribeiro MF, Donini LP, Souza JÁ, Guisso AP, Moura IF, Bobrowski VL, Viégas J (2007) Influência de diferentes concentrações de sais de MS e açúcares no cultivo in vitro de manjericão roxo (Ocimum basilicum L.) Rev Brasil Biocie.5(2):57-59.

Rodrigues FA, Penoni E S, Soares JDR, Pasqual M (2013) Different concentrations of the MS medium and BAP on multiplication in vitro of Physalis peruviana L. Bioscience J. 29(1):77-82

Roycewicz P, Malamy JE (2012) Dissecting the effects of nitrate, sucrose and osmotic potential on Arabidopsis root and shoot system growth in laboratory assays. Phil Trans $\mathrm{R}$ Soc. B.367:1489-1500.

Sáenz L, Herrera-Herrera G, Uicab-Ballote F, Chan JL, Oropeza $C$ (2010) Influence of form of activated charcoal on embryogenic callus formation in coconut (Cocos nucifera). Plant Cell Tiss Organ Cult.100:301-308.

Saha S, Kader A, Sengupta C, Ghosh P (2012) In vitro propagation of Ocimum gratissimum L. (Lamiaceae) and its evaluation of genetic fidelity using RAPD marker. Am J Plant Sci. 3(1):64-74.

Shabala S, Cuin TA (2007) Potassium transport and plant salt tolerance. Physiol Plant. 133(4): 651-669.

Shafran E, Dudai N, Mayer AM (2007) Polyphenol oxidase in Ocimum basilicum during growth, development and following cold stress. J Food Agric Environ. 5(3\&4): 254-257.

Silva HFJ, Asmar AS, Oliveira RC, Luz JMQ, B (2016) Alternative supplements and MS medium concentration in the in vitro establishment of Dipteryx alata Vog. Bioscience J. 32 (5):1138-1146

Silvia MLS, Trevizam AR (2015) Interações iônicas e seus efeitos na nutrição de plantas. Inform Agron. 149:10-16.

Simon JE, Morales MR, Phippen WB, Vieira RF, Hao Z (1999) Basil: a source of aroma compounds and a popular culinary and ornamental herb. J Am Soc Hortic Sci. 4:499-505.

Swamy MK, Mohanty SK, Anuradha M (2014) The effect of plant growth regulators and natural supplements on in vitro propagation of Pogostemon cablin Benth. J Crop Sci Biotech.17(2):71-78.

Taie HAA, Salama ZAR, Radwan S (2010) Potential activity of basil plants as a source of antioxidants and anticancer agents as affected by organic and bio-organic fertilization. Not Bot Hort Agrobot Cluj. 38(1):119-127

Telci I, Bayram E, Yilmaz G, Avci B (2006) Variability in essential oil composition of Turkish basils (Ocimum basilicum L.). Biochem Syst Ecol. 34(6):489-497.

Thomas TD (2008) The role of activated charcoal in plant tissue culture. Biotechnolo Adv. 26(6):618-631.

Torres AC, Duval FG, Ribeiro DG, Barros AFF, Aragão FAD (2005) Effect of sucrose, kinetin, isopentenyl adenine and zeatin on the development of embryos of Heliconia rostrata in vitro Hort Brasil.23(3):789-792.

Valmorbida J, Boaro CSF, Scavroni J, David EFS (2007) Crescimento de Mentha piperita L., cultivada em solução nutritiva com diferentes doses de potássio. Rev Bras Plantas Med. 9(4): 27-31.

Vieira RF, Simon JE (2006) Chemical characterization of basil (Ocimum spp.) based on volatile oils. Flavour Frag J. 21(2):214-221

Wang M, Zheng Q, Shen Q, Guo S (2013) The critical role of potassium in plant stress response. Int J Mol Sci.14(4): 73707390.

Yaseen M, Ahmad T, Sablok G, Standardi A, Hafiz IA (2013) Review: role of carbon sources for in vitro plant growth and development. Molecular. 40(4):2837-2849.

Yruela I (2005) Copper in plants. Braz J Plant Physiol.17(1):145156.

Zavariyan AM, Rad MY, Asghari M (2015) Effect of seed priming by potassium nitrate on germination and biochemical indices in Silybum marianum L. under salinity stress. Int J Life Sci. 9(1):23-29.

Zhang R, Zhang B, He T, Yi T, Yang J, He B (2016) Increase of rutin antioxidant activity by generating maillard reaction products with lysine. Bioorg Med Chem Lett. 26(11): 26802684 